\title{
Effect of Tillage and Straw Returning on Nitrogen Reserves in Summer Corn Topsoil
}

\author{
Xiujuan Ren, Yanan Cheng*, Dafu Wu, Chunhu Wang and Shilin Chen
}

Henan Institute of Science and Technology, Xinxiang, Henan Province, China

\begin{abstract}
A field experiment with six treatments was conducted to study the nitrogen reserves in summer maize topsoil on the north China plain. Results showed that topdressing significantly increased topsoil nitrogen reserves. Summer corn topsoil nitrogen reserves were affected by several management measures. Shallow tillage, wheat straw no-returning and deep intertillage at the corn seedling stage significantly decreased topsoil nitrogen reserves, while wheat straw returning, no-tillage and biogas residue application during the wheat planting season significantly increased topsoil nitrogen reserves. The topsoil nitrogen reserve of Treatment 5 (straw returning + biogas residue + no-tillage + no-intertillage at the corn seedling stage) (biogas residue applied in the wheat season) increased by $629.55 \mathrm{~kg} / \mathrm{ha}$ in the corn season. In Treatment 2 (straw returning + no-tillage + no-intertillage at corn seedling stage), topsoil nitrogen reserve increased by 445.2 $\mathrm{kg} / \mathrm{ha}$. Topsoil nitrogen storage showed the largest decrease in Treatment 3 (straw returning + no-tillage + intertillage at corn seedling stage), with a reduction of $1283.85 \mathrm{~kg} / \mathrm{ha}$. The topsoil $\mathrm{N}$ storage of Treatment 4 (straw returning + shallow (spin) tillage + no-intertillage at corn seedling) stage, Treatment 1 (straw no-returning + no-tillage + no-intertillage at corn seedling stage) and Treatment 3 (straw returning + no-tillage + intertillage at corn seedling stage) decreased by 935.7 $\mathrm{kg} / \mathrm{ha}, 399.3 \mathrm{~kg} / \mathrm{ha}$ and $351.9 \mathrm{~kg} / \mathrm{ha}$, respectively.
\end{abstract}

Keywords: Shallow tillage, topsoil, topsoil nitrogen reserve, wheat straw returning.

\section{INTRODUCTION}

In the North China plain, the important agricultural production system is Winter wheat summer maize rotation. The application of excessive nitrogen fertilizer is considered as a common problem in the local agricultural production system. Previous agronomy research has emphasized improving the nitrogen fertilizer utilization rate to increase crop yield [1]. With the rise in public environmental awareness, however, the impact of farmland nitrogen loss on the environment has received increasing attention [2-4].

China is vigorously developing the concept and practice of circular agriculture so as to, among other objectives, minimize agricultural non-point source pollutant emissions [5]. The impact of tillage and straw returning on topsoil nitrogen reserves has been studied in China. Hu et al. compared soil organic carbon and nitrogen reserve under conventional tillage and six-year no-tillage straw mulch, and showed that, compared with plowing, no-tillage treatment mulch increased organic carbon and nitrogen reserves in the $0-15 \mathrm{~cm}$ topsoil, to some extent, but did not affect the reserves deeper than $15 \mathrm{~cm} \mathrm{[6].}$

A seventeen-year field experiment in red paddy soil showed that long-term organic material recycling significantly increased topsoil total nitrogen, with nitrogen reserves increasing by an average of $18.8 \%$ compared with that before the experiment. Chen et al. opined it was feasible to reduce nitrogen fertilizer application from $262.5 \mathrm{~kg} / \mathrm{ha}$ to
$180 \mathrm{~kg} / \mathrm{ha}$ in conjunction with half straw returning [7]. Zhao et al. found that wheat straw returning improved the utilization rate of nitrogen fertilizer in summer corn and reduced the nitrate- $\mathrm{N}$ residue in $0-20 \mathrm{~cm}$ topsoil [8]. A seven-year field experiment by Wang et al. demonstrated that soil total nitrogen content in the $0-30 \mathrm{~cm}$ topsoil with wheat-bean rotation and straw mulch and with conventional tillage and straw returning was higher than that with no-tillage, nomulch and conventional tillage [9]. International research has also shown that measures such as reduction of tillage and fertilizer application and crop rotation improved organic nitrogen and mineral nitrogen reserves in farmland $[10,11]$.

On the one hand, excessive application of nitrogen fertilizer may produce non-point pollution, on the other hand, it may reduce the use efficiency of nitrogen fertilizer also.Over the last decade, chemical fertilizer application in Henan province has increased by an average of $10 \%$ annually. In addition, there is greater surface application of chemical fertilizer than deep fertilizer placement, resulting in a low NUE and serious fertilizer loss, with a significant amount of unused fertilizer transported into surface water, air and other ecological environments through runoff and leaching [12]. Irrational fertilizer application (especially of nitrogen) is the main reason of agricultural area pollution. The average utilization rate of nitrogen fertilizer of various crops is $40 \%$ to $50 \%$, with most unutilized nitrogen lost via runoff into water [13]. Therefore the current fertilization and tillage mode need to be changed to reduce farmland fertilization and improve nitrogen utilization, Henan province is the major grain producing zone of China and its main cropping pattern is winter wheat-summer maize rotation. Changes in nitrogen reserves in summer corn crop soil under combined tillage 
and straw returning have received little attention. Accordingly, in this study, winter wheat-summer maize cropping farmland in northern China was investigated in relation to the effects of various tillage and straw returning methods on nitrogen reserves in summer maize topsoil $(0-20 \mathrm{~cm})$ at different growth stages.

\section{EXPERIMENTAL DESIGN AND METHODS}

\subsection{Experimental Design}

A filed experiment was set up from June 2013 to September 2013 in Qian Li Village, Huojia County, on a calcareous alluvia soil typical for the North China. The experimental plot is carried out with three replications and with the method of random distribution. The width of plot is 15 meters, the length is $20 \mathrm{~m}$. Soil texture was loamy and the bulk density was $1.45 \mathrm{~g} / \mathrm{cm}^{-3}$ at $0-20 \mathrm{~cm}$ layer, other soil test items of the $0-20 \mathrm{~cm}$ sample were: $\mathrm{pH}(1: 1$, soil/water $) 7.9$, total $\mathrm{N}$ $1.32 \mathrm{~g} / \mathrm{kg}$, total $\mathrm{P} 1.25 \mathrm{~g} / \mathrm{kg}$, total $\mathrm{K} 10.12 \mathrm{~g} / \mathrm{kg}$, Olsen P36.56 mg/kg, exchangeable K $356 \mathrm{mg} / \mathrm{kg}$, organic matter $13.54 \mathrm{~g} / \mathrm{kg}$. The six treatments were: 1 . Straw no-returning + no-tillage + no-intertillage at corn seedling stage; 2 . Straw returning + no-tillage + no-intertillage at corn seedling stage; 3. Straw returning + no-tillage + intertillage at corn seedling stage; 4. Straw returning + shallow (spin) tillage + nointertillage at corn seedling stage; 5. Straw returning + biogas residue + no-tillage + no-intertillage at corn seedling stage (biogas residue was applied at wheat season with 22 $500 \mathrm{~kg} / \mathrm{ha}$ ); and 6. Straw no-returning + shallow tillage + nointertillage at corn seedling stage.

Zhengdan 958 varieties was chosen with an output of $9,750 \mathrm{~kg} / \mathrm{ha}$, and density of 67,500/ha. The corn was planted on June 4, 2013 with array pitch of $0.67 \mathrm{~m}$ and plant spacing of $0.22 \mathrm{~m}$. Timely watering after planting was performed to achieve full germination, and the harvest date was September 23, 2013.

At the time of sowing, $22.5 \mathrm{~kg}$ of zinc sulfate trace fertilizer was applied per hectare. The amounts of applied N, P and $\mathrm{K}$ fertilizer were calculated according to the target output. The ratios of $\mathrm{N}: \mathrm{P}_{2} \mathrm{O}_{5}: \mathrm{K}_{2} \mathrm{O}$ for every $100 \mathrm{~kg}$ target yield was 2.8:0.8:3.0. The $\mathrm{K}$ and $\mathrm{P}$ fertilizer were applied in each plot at the seedling stage, $\mathrm{N}$ fertilizer was applied on July 15 , and $225 \mathrm{~kg} / \mathrm{ha}$ of urea was applied on August $10(37 \%$ of total $\mathrm{N}$ fertilizer).

\subsection{Method of Sampling}

Ten plants were randomly selected at the elongation stage (June 30, 2013), big flare stage (July 20, 2013), anthesis stage (August 2, 2013), filling stage (August 21, 2013) and maturity stage (September 23, 2013) to determine dry matter weight and total nitrogen of the root, stem, leaf, tassel and ear. Topsoil samples were collected at the various growth stages to measure soil organic matter, soil total nitrogen, soil mineral nitrogen $\left(\mathrm{N}_{\min }\right)$ and soil bulk density.

\subsection{Determination Method and Data Analysis}

Soil and plant total-N was ascertained by the Kjeldahl method, soil bulk density was measured by the ring knife method, and dry matter weight was found by the drying method.
The data comparisons among means were made using the two - factor variance analysis, calculated the $\mathrm{P}$ value and analysis the significant at two level 0.05 or 0.01 . All statistical analyses were performed with SPSS 11.5.

\section{RESULTS AND ANALYSIS}

\subsection{The Nitrogen Absorption and Utilization of Different Treatment on Summer Maize}

The yield of each treatment was significantly higher than that of the target yield value (Table 1), there was significant difference of crop yields between the six treatments. A higher-yielding maize variety (Zhengdan 958) was used in the six treatments but without changing in the target $N$ supply value, hence the grain yield in the treatment 5 was higher than that in the other treatments.

Nitrogen harvesting index reflects the proportion of plant nitrogen into the grain, in this experiment, the nitrogen harvesting index of the treatment 6 (no straw returning + shallow tillage + no-intertillage) reached maximum. The nitrogen harvesting index of treatment 3 (Straw returning + no-tillage + intertillage) is minimum. Treatment 3 in seedling stage was conducted cultivating treatment, may be one of the reasons leading to the low nitrogen harvest index. Wheat straw returning is also a reason to have certain effect to the nitrogen harvest index, two higher nitrogen harvest index of treatment all with no straw returning.

Table 1. The nitrogen absorption and utilization of different treatment on summer maize.

\begin{tabular}{|c|c|c|c|c|}
\hline Treatment & $\begin{array}{c}\text { Grain } \\
\text { yield/(kg/ha) }\end{array}$ & $\begin{array}{c}\text { Biomass/( } \\
\mathbf{k g} / \mathbf{h a})\end{array}$ & $\begin{array}{c}\mathbf{1 0 0 0 - G r a i n} \\
\text { mass/g }\end{array}$ & $\begin{array}{c}\text { Harvesting } \\
\text { index/\% }\end{array}$ \\
\hline \hline 1 & $11813.70^{\mathrm{d}}$ & $24375.60^{\mathrm{c}}$ & $370^{\mathrm{a}}$ & $75.05^{\mathrm{ab}}$ \\
\hline 2 & $12300.75^{\mathrm{c}}$ & $28262.70^{\mathrm{b}}$ & $350^{\mathrm{b}}$ & $72.83^{\mathrm{b}}$ \\
\hline 3 & $11434.50^{\mathrm{e}}$ & $26975.03^{\mathrm{c}}$ & $350^{\mathrm{b}}$ & $59.34^{\mathrm{d}}$ \\
\hline 4 & $12675.45^{\mathrm{b}}$ & $32403.15^{\mathrm{a}}$ & $340^{\mathrm{b}}$ & $62.01^{\mathrm{c}}$ \\
\hline 5 & $13070.25^{\mathrm{a}}$ & $27108.45^{\mathrm{b}}$ & $370^{\mathrm{a}}$ & $74.14^{\mathrm{a}}$ \\
\hline 6 & $12940.95^{\mathrm{a}}$ & $30146.40^{\mathrm{a}}$ & $360^{\mathrm{b}}$ & $77.24^{\mathrm{a}}$ \\
\hline
\end{tabular}

Notes: $\mathrm{N}=3$, lower case letters represent significant differences $(P<0.05)$.

\subsection{Total Nitrogen Reserve in Topsoil under Different Treatments During Each Growth Stage}

Table 2 showed that topsoil total nitrogen exhibited different trends under different treatments at the various growth stages. After topdressing with nitrogen fertilizer on July 15, the topsoil total nitrogen increased significantly in Treatments 1(Straw no-returning + no-tillage + no-intertillage at corn seedling stage;), 2(Straw returning + no-tillage + nointertillage at corn seedling stage), 3(Straw returning + notillage + intertillage at corn seedling stage) and 4(Straw returning + shallow (spin) tillage + no-intertillage at corn seedling stage), but did not show significant changes in Treatments 5(Straw returning + biogas residue + no-tillage + nointertillage at corn seedling stage (biogas residue was applied 
Table 2. Topsoil total nitrogen reserve of each treatment at different growth stages $(\mathrm{kg} / \mathrm{ha})$.

\begin{tabular}{|c|c|c|c|c|c|c|}
\hline Growth stages & 1 & 2 & 3 & 4 & 5 & 6 \\
\hline Elongation stage & $3891.62^{\mathrm{c}}$ & $2802.41^{\mathrm{a}}$ & $3363.82^{\mathrm{a}}$ & $3997.23^{b}$ & $1936.41^{\mathrm{a}}$ & $3010.42^{\mathrm{c}}$ \\
\hline Big flare stage & $5656.43^{\mathrm{d}}$ & $5239.23^{\mathrm{c}}$ & $4316.44^{\mathrm{c}}$ & $5544.43^{\mathrm{c}}$ & $2450.01^{\mathrm{a}}$ & $3027.62^{\mathrm{c}}$ \\
\hline Anthesis stage & $3625.62^{\mathrm{c}}$ & $4035.62^{\mathrm{b}}$ & $3582.82^{\mathrm{b}}$ & $3357.22^{\mathrm{a}}$ & $3148.22^{\mathrm{b}}$ & $2921.61^{\mathrm{b}}$ \\
\hline Maturity stage & $3477.62^{\mathrm{b}}$ & $3212.02^{\mathrm{a}}$ & $3068.82^{\mathrm{a}}$ & $3080.02^{a}$ & $2543.81^{\mathrm{a}}$ & $1710.01^{\mathrm{a}}$ \\
\hline
\end{tabular}

Notes: $\mathrm{N}=3$, lower case letters represent significant differences $(P<0.05)$.

Table 3. Nitrogen reserve gain and loss in summer corn topsoil during the whole reproductive period (unit: $\mathrm{kg} / \mathrm{ha}$ ).

\begin{tabular}{|c|c|c|c|c|c|}
\hline Treatment & $\begin{array}{c}\text { Topsoil total nitrogen at } \\
\text { elongation stage }\end{array}$ & $\begin{array}{l}\text { Nitrogen } \\
\text { fertilizer }\end{array}$ & $\begin{array}{l}\text { Corn plant nitrogen } \\
\text { at mature stage }\end{array}$ & $\begin{array}{l}\text { Topsoil total nitro- } \\
\text { gen at mature stage }\end{array}$ & $\begin{array}{l}\text { Topsoil nitrogen } \\
\text { gain or loss }\end{array}$ \\
\hline 1 & 3891.6 & 273 & 287.7 & 3477.6 & $-399.3^{b}$ \\
\hline 2 & 2802.45 & 273 & 308.55 & 3211.95 & $445.2^{\mathrm{c}}$ \\
\hline 3 & 3363.75 & 273 & 216.15 & 3068.85 & $-351.9^{\mathrm{b}}$ \\
\hline 5 & 1936.35 & 273 & 295.2 & 2543.85 & $629.55^{\mathrm{c}}$ \\
\hline 6 & 3010.35 & 273 & 289.5 & 1710 & $-1283.85^{\mathrm{a}}$ \\
\hline
\end{tabular}

Notes: Topsoil nitrogen gain and loss = topsoil total nitrogen at mature stage + corn plant nitrogen at mature stage - nitrogen fertilizer - topsoil total nitrogen at mature stage, in triplicate. ${ }^{\mathrm{a}},{ }^{\mathrm{b}},{ }^{\mathrm{c}}$ and ${ }^{\mathrm{d}}$ represent significant differences $(P<0.05)$. Negative numbers represent nitrogen deficiency, positive numbers represent nitrogen gain.

at wheat season)) and 6(Straw no-returning + shallow tillage + no-intertillage). After topdressing with the remaining $37 \%$ nitrogen on August 10, topsoil total nitrogen reserves at the filling stage compared with the anthesis stage decreased significantly in Treatments 1 and 2, decreased slightly in Treatments 4 and 5, increased slightly in Treatment 3, and increased significantly in Treatment 6. During the whole reproductive stage, topsoil total nitrogen reserves at the mature stage compared with the elongation stage decreased significantly in Treatments 1,4 and 6 , decreased slightly in Treatment 3, and increased slightly in Treatments 2 and 5.

\subsection{Topsoil Nitrogen Losses and Earnings of Each Treat- ment}

The main sources of nitrogen in topsoil include soil nitrogen, chemical fertilizer, organic fertilizer, irrigation, nitrogen deposition and biological nitrogen fixation. After crops are planted, nitrogen from soil and chemical fertilizer are the topsoil initial nitrogen input. After harvest, the final nitrogen reserve amount can be considered as the sum of crop nitrogen uptake and total nitrogen reserve in topsoil. The differences between total nitrogen input and the final nitrogen reserve are the topsoil nitrogen gains and losses.

The results in Table 3 show that nitrogen accumulated in Treatments 2 and 5, but was deficient in the other treatments. Topsoil nitrogen loss in Treatment 6 was significantly higher than Treatment 1 , and Treatment 4 was higher than Treatment 3 . Treatments 4 and 6 were both under shallow tillage before corn planting. These results illustrated that regardless of whether wheat straw was returned or not, tillage before corn planting increased nitrogen loss. The accumulation of topsoil nitrogen in Treatment 2, but deficiency in Treatment 3 , illustrated that the deep intertillage of topsoil at the corn seedling stage accelerated nitrogen loss. Topsoil cumulative nitrogen in Treatment 5 was higher than Treatment 2, although wheat straw returning + no-tillage + no-intertillage at the corn seedling stage were applied in both treatments. However, the biogas residue organic fertilizer applied in Treatment 5 at the wheat planting season promoted wheat straw humification and higher topsoil nitrogen accumulation.

\section{RESULTS AND DISCUSSION}

\subsection{Results}

Fertilization, field tillage and straw returning all affected the reserves of topsoil total nitrogen in this studied corn fields. Topsoil nitrogen reserves increased significantly after fertilizer application at the elongation stage and tended to decrease from the corn filling stage to the maturity stage. Field management measures such as wheat straw noreturning, shallow tillage and deep intertillage at the corn seedling stage caused topsoil nitrogen deficiency, while wheat straw returning, no-tillage, and no-intertillage at the corn seedling stage and biogas organic fertilizer application at wheat planting were beneficial to topsoil nitrogen accumulation. 


\subsection{Discussion}

Because soil bulk density influences the calculation of topsoil total nitrogen reserves, tillage can lead to soil bulk density decrease, and thus indirectly to reduced topsoil nitrogen reserves. This study explored the changes in topsoil nitrogen reserves, and found that field management measures such as shallow, wheat straw-returning and intertillage affected topsoil nitrogen migration and transformation during the corn growth season. Currently, several methods have been developed to calculate the nitrogen utilization rate. Zhang et al. defined the utilization rate as the recovery efficiency of crops to applied nitrogen fertilizer in soil [14], while Lin et al. defined the rate as the proportion of nitrogen absorbed by a crop to that applied to farmland in the crop season, not including nitrogen losses and residue in the soil [15]. However, other research has claimed that it is difficult to distinguish nitrogen absorbed by plants and topsoil nitrogen [16]. Hence, the definition and calculation of the nitrogen utilization rate requires further study in relation to crop rotation.

The loss of nitrogen fertilizer was due to the traditional nitrogen application. Karlen et al. found that nitrogen fertilizer utilization was only $50 \%$.

Because of low precipitation and high transpiration, $\mathrm{N}$ leaching is not an important pathway of $\mathrm{N}$ losses in the winter wheat-summer maize rotation system in the North China Plain [17]. However, there is increasing evidence showing $\mathrm{NO}_{3}-\mathrm{N}$ leaching occurring in low-rainfall regions under certain circumstances $[18,19]$.

Nitrate movement in the soil main depends on the water movement near the topsoil. The supply of more water than the requirement of crop may cause more $\mathrm{N}$ leaching. Generally, nitrogen leaching in irrigated farm was high than dry land [20].

In this experiment, considering the reserves of straw and tillage on Maize topsoil nitrogen effect, the results of the study show that, according to the target yield amount of applying nitrogen fertilizer, different processing maize yield, nitrogen harvest index, nitrogen, nitrogen loss of topsoil tilth reserves were significantly different. There was significant difference of crop yields between the six treatments, the grain yield of the treatment 5 was higher than that in the other treatments. Nitrogen harvesting index reflects the proportion of plant nitrogen into the grain, in this experiment, the nitrogen harvesting index of the treatment 6 (no straw returning + shallow tillage + no-intertillage) reached maximum. The nitrogen harvesting index of treatment 3 (Straw returning + no-tillage + intertillage) is minimum. During the whole growing stage, topsoil total nitrogen reserves at the mature stage compared with the elongation stage decreased significantly in Treatments 1,4 and 6, decreased slightly in Treatment 3 , and increased slightly in Treatments 2 and 5. Hence, the straw no returning and frequent tillage may be the main factor, Further studies are needed to study the reason causing the decrease of nitrogen content in topsoil.

Nitrogen accumulated in Treatments 2 and 5, but was deficient in the other treatments. Topsoil nitrogen loss in Treatment 6 was significantly higher than other treatments, this results illustrated that regardless of whether wheat straw was returned or not, tillage before corn planting increased nitrogen loss. The accumulation of topsoil nitrogen in Treatment 2, but deficiency in Treatment 3, illustrated that the deep intertillage of topsoil at the corn seedling stage accelerated nitrogen loss. Topsoil cumulative nitrogen in Treatment 5 was higher than Treatment 2, although wheat straw returning + no-tillage + no-intertillage at the corn seedling stage were applied in both treatments. However, the biogas residue organic fertilizer applied in Treatment 5 at the wheat planting season promoted wheat straw humification and higher topsoil nitrogen accumulation, further studies are needed on soil nitrogen reserves the effect of biogas residue.

Compared with conventional tillage and no tillage, conservation tillage could improve the soil infiltration ability, and improved the utilization efficiency of fertilizer [21]. The returning straw on the ground forming a buffer layer, buffer rain destruction on soil aggregates and water conservation $[22,23]$. On the farmland ecological system, study the effects of different tillage and fertilization measures on the changes of topsoil nitrogen reserves from on macroscopic has more value and significance of social practice.

\section{CONFLICT OF INTEREST}

The authors confirm that this article content has no conflict of interest.

\section{ACKNOWLEDGEMENTS}

This work was funded by the "12th Five Year Plan" Circular Agriculture Science and Technology Project Central Plains Economic Zone Agricultural Circular Technologies Integration and Demonstration, Project No. 2012BAD14B08-1.

\section{REFERENCES}

[1] D.R. Lewis, M.B. McGechan, and I.P. McTaggart, "Simulating field-scale nitrogen management scenarios involving fertilizer and slurry applications, "Agricultural Systems, vol. 76, no. 1, pp. 1591801, 2003.

[2] M.J. Goss, E.G. Beauchamp, and M.H. Miller, "Can a farming systems approach help minimize nitrogen losses to the environment," Journal of Contaminant Hydrology, vol. 20, no. 3-4, pp. 285-2971, 1995.

[3] S.O. Oikeh, R.J. Carsky, J.G. Kling, V.O. Chude, and W.J. Horst, "Different $\mathrm{N}$ uptake by corn cultivars and soil nitrate dynamics under $\mathrm{N}$ fertilization in West Africa agriculture," Ecosystems and Environment, vol. 100, no. 2-3, pp. 181-1911, 2003.

[4] D.S. Jenkinson, "The impact of humans on the nitrogen cycle, with focus on temperate arable agriculture," Plant and Soil, vol. 228, no. 1, pp. 3-151, 2001.

[5] C.B. Yin, Y. Zhou, and L.H. Liu, "Theory and practice of recycle agriculture in China," Chinese Journal of Eco-Agriculture, vol. 21, no. 1, pp. 47-53, 2013. (In Chinese)

[6] N. Hu, Y.L. Lou, and L. Liang, "Soil organic C and N stocks as affected by the conservation tillage," Ecology and Environmental Science, vol. 18, no. 6, pp. 223-226, 2009. (In Chinese)

[7] A.L. Chen, X.L. Xie, W.Y. Wen, W. Wang, and C.L. Tong, "Effect of long term fertilization on soil profile nitrogen reserve in a reddish paddy soil," Acta Ecologica Sinica, vol. 30, no. 18, pp. 50595065, 2010. (In Chinese)

[8] P. Zhao, F. Chen, "Effect of straw mulching and nitrogen fertilizer application on nitrogen use in summer corn and soil nitrate content," Journal of Henan Agricultural University, vol. 43, no. 1, pp. 14-18, 2009. (In Chinese) 
[9] J. Wang, L.Q. Cai, D.M. Bi, X.J. Wang, and R.Z. Zhang, "Effects of conservation tillage on the SOC, TN, SMBC and SMBN in two sequence rotation systems with spring wheat and pea," Journal of Agro-Environment Science, vol. 28, no. 7, pp. 1516-1521, 2009. (In Chinese)

[10] C.A. Campbell, F. Selles, G.P. Lafond, V.O. Biederbeck, and R.P. Zentner, "Tillage-fertilizer changes: effect on some soil quality attributes under long-term crop rotations in a thin Black Chernozem," Canada Journal Soil Science, vol. 81, pp. 157-165, 2001.

[11] S.S. Malhi, S.A. Brandt, R. Lemke, A.P. Moulin, and R.P. Zentner, "Effects of input level and crop diversity on soil nitrate-N, extractable $\mathrm{P}$, aggregation, organic $\mathrm{C}$ and $\mathrm{N}$, and $\mathrm{N}$ and $\mathrm{P}$ balance in the Canadian Prairie," Nutrition Cycle Agroecosystme Online, doi: 10.1007/s10705-008-9220-0, 2009.

[12] L.L. Zhao, C.L. Zhong, and Y. Li, "Situation of agricultural nonpoint pollution and countermeasures in Henan Province. Guangdong," Agricultural Sciences, vol. 7, pp. 186-189, 2010. (In Chinese)

[13] J. Zhou, "The pollution hazards of agricultural non-point source," Agriculture Environmental Protection, vol. 9, no. 1, pp. 22-24, 451, 1990. (In Chinese)

[14] F.S. Zhang, J.Q. Wang, W.F. Zhang, Z.L. Cui, W.Q. Ma, X.P. Chen, and Jang R.F., "Nutrient use efficiencies of major cereal crops in China and measures for improvement," Acta Pedologica Sinica, vol. 45, no. 5, pp. 915-924, 2008. (In Chinese)

[15] D. Lin., "Soil and Fertilizer Institute", Chinese Academy of Agricultural Sciences, China Fertilizer. Shanghai: Shanghai Scientific and Technical Publishes, pp. 225-233, 1994. (In Chinese)
[16] S.M. Shen, "A conjecture on the fertilizer recovery measurement by field experiment," Chinese Journal of Applied Ecology, vol. 16, no.5, pp. 781-782, 2005. (In Chinese)

[17] Z. Zhu, and Q. Wen, "Soil nitrogen in China," Jiangsu Science And Technique Public, Nanjing, 1992. (In Chinese)

[18] W.M. Strong, "Nitrogen fertilizer of upland croos," In P.E. Bacon Ed. Nitrogen Fertilization in the Environment, Marcel Dekker, New York, 1995, pp. 129-170.

[19] M.R. Cameira, R.M. Fernando, and L. Pereira, "Monitoring Water and NO3-N in irrigated maize fields in the Sorraia Watershed. Portugal," Agricculture Water Management, vol. 60, pp. 199-216, 2003.

[20] J.A. Diez, R. Caballero, R. Roman, A. Tarquis, M.C. Cartagena, and A. Vallejo, "Integrated fertilizer and irrigation management to reduce nitrate leaching in central Spain," Journal of Environmental Quality, vol. 29, pp. 1539-597, 2000.

[21] N. Verhulst, B. Govaerts, E. Verachtert, A. Castellanos-Navarrete, M. Mezzalama, P. Wall, J. Deckers, and K. D. Sayre, "Conservation agriculture, improving soil quality for sustainable production systems?," In: R. Lal, and B.A. Stewart, Eds., Advances in Soil Science: Food Security and Soil Quality, CRC Press, Boca Raton, 2010, pp. 137-208.

[22] Y. L. Bissonnais, "Aggregate stability and assessment of soil crustability and Erodibility, Theory and Methodology", European Journal of Soil Science, vol. 47, pp. 425 -437, 1996.

[23] S.L. Zhang, E. Simelton, L. Lovdahl, H. Grip, and D.L. Chen, "Simulated long-term effects of different soil management regimes on the water balance in the Loess Plateau, China". Field Crops Research, vol. 100, pp. $311-319,2007$.

Received: February 03, 2015

Revised: April 03, 2015

Accepted: May 25, 2015

(C) Ren et al.; Licensee Bentham Open.

This is an open access article licensed under the terms of the (https://creativecommons.org/licenses/by/4.0/legalcode), which permits unrestricted, noncommercial use, distribution and reproduction in any medium, provided the work is properly cited. 